The Geneva Papers on Risk and Insurance, 21 (No. 81, October 1996), 435-468

\title{
Preventing Conflicts Between Generations
}

\author{
For An Active Management of the Allocation of Resources Between Generations*
}

by Denis Kessler**

\begin{abstract}
It takes more than one generation before an olive tree bears fruit. A newly planted forest takes about one century before rising to its full height. Generations come and go before anything can be gained from the ground where a swamp was drained and, regardless of the reasons that those who planted the olive trees and the forests or drained the swamps had, it is possible that they gave little or no thought to the norms which dictated their behaviour and to the function of these norms: to ensure collective survival.
\end{abstract}

Dieter Birnbacher, «La responsabilité envers les générations futures», PUF, 1994

It cannot be denied that, over the decades to come, there will be much debate, criticism and questioning on the whole issue of intergenerational transfers. In fact, the demographic upheaval that industrialized countries will have to face will bring about a breakdown in the relative equilibrium of present-day intergenerational transfer mechanisms. This demographic bust has no precedent (Part 1). It will affect the whole spectrum of intergenerational transfers, whether they go up or down the generation chain, whether they are public or private, or the result of individual or collective choice (Part 2). It is vital

* This is an English translation of a paper originally written in French: «Prévenir les conflits entre les générations». It is also the text of reference of the 20th Annual Lecture of the Geneva Association given by Prof. Denis Kessler at the London School of Economics, on February 1st, 1996.

**Ecole des Hautes Etudes en Sciences Sociales and Fédération Française des Sociétés d'Assurances. 
to elaborate a real policy for the management of these transfers in order to avoid tension, or indeed conflict, that would jeopardize the cohesion of society and which, if allowed to worsen, could result in very serious crisis situations (Part 3).

\section{An unprecedented demographic bust}

In order to outline the current and especially the future evolution of the relative balance of the various age groups, and to assess the way in which it is likely to affect the system of intergenerational transfers, we must first examine, successively, the evolution of fertility and mortality rates, and of migratory phenomena.

\subsection{Is the fertility rate down for the long term?}

Whether admitted or not, the demographic situation in France began to change in the mid-sixties, in 1964 to be more exact. The fertility rate, which had been very high since 1945, collapsed at that time, dropping from 2.9 children per woman to 1.65 children per woman in 1994. It should be stressed that this change in behaviour also occurred in the other developed countries, as shown in Chart 1.

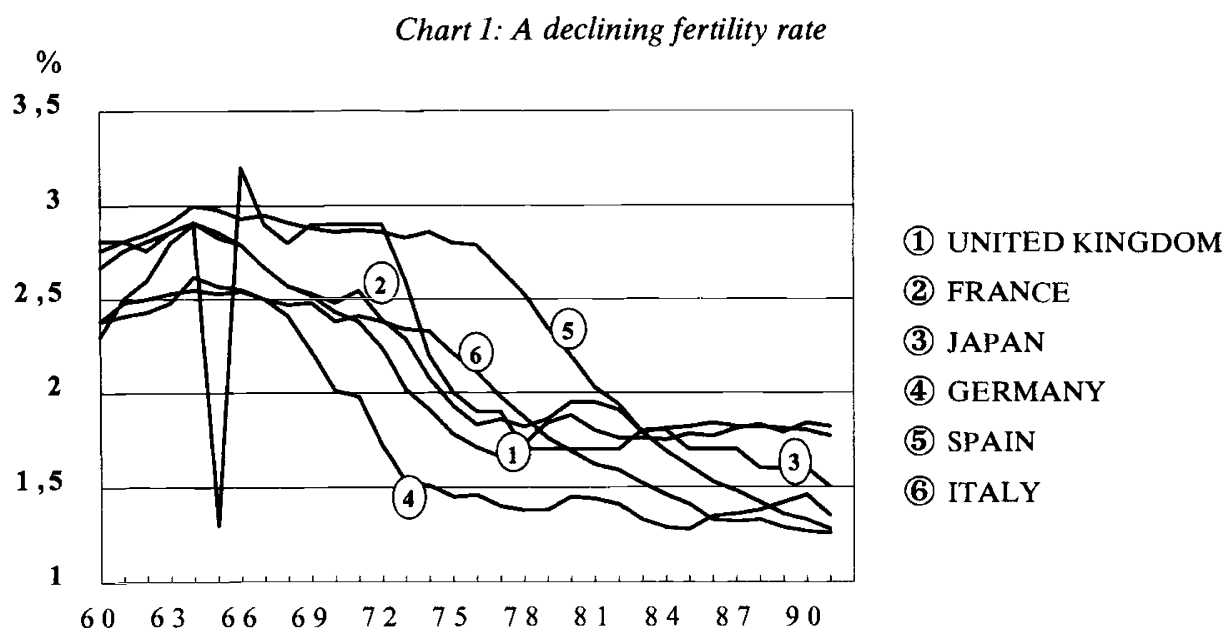

Source: O.E.C.D.

The similarities in the changes in demographic behaviour among the O.E.C.D. countries is striking. Why did the baby boom, which concerned almost all of the post-war industrialized countries, come to an end everywhere at almost the same time, while there are so many differences between these countries, such as, for example, religious beliefs, the relative level of development, urban density or the number of women in the work force?

No really convincing argument has been put forward to explain this shift from the «baby boom» to the «baby bust». The reasons for this transition remain largely unknown. The fact that it is practically impossible to explain the past trend in the fertility rate makes it difficult to outline its future. There are two theories on the subject. 
The first one postulates that the fertility rate is cyclical (i.e., the «Easterlinian» theory). It can be presented simply: a «full» generation produces an «empty» one and an «empty» one produces a full one. There are numerous arguments drawn from both economic and sociological sources which, of course, support the theory of the cyclical nature of the fertility rate. It is not our purpose to recall them here.

The opposite theory claims that fertility rate patterns are not necessarily reversible, which, if true, means that the decline we have seen over the last thirty years will be a lasting one. Industrialized societies have entered a long period of low fertility rates. The «baby boom» is an abnormal phenomenon, in total contradiction with the age-old trend of a decreasing fertility rate. It is simply a historical accident which has been putting itself right since the sixties. One can thus understand just how difficult it is to explain this atypical development.

The question regarding the future trend in the fertility rate is an important one, especially for the assessment of the very long-term relative balance among the various coexisting generations. To wager that the present situation will continue is safer than assuming that there will be a return to fertility rates as high as those which were seen from 1945 to 1965. In any case, the question of a possible return to high fertility rates is important, but not paramount, if we do not look beyond the next thirty years. In fact, the real change in the relative balance among age groups will take place no matter what happens because, to quote a terrible, but nevertheless true expression, «the children who have not been born over the last thirty years will never be born.»1

Thus, it appears that a fertility rate of 1.8 children per woman is the most likely assumption, even if this average fluctuates occasionally. As with any other «accident», a return to the baby boom phenomenon could be possible, but if it were to occur, it would affect most of the intergenerational transfers only at the end of the period under consideration, or beyond it.

\subsection{Is the mortality rate declining steadily?}

The trend in the mortality rate is also well known. Mortality rates per age group fall steadily as the generations come and go. If one looks at the evolution of life expectancy over a long period in France (Chart 2 ), ${ }^{2}$ one notes that the real acceleration of life expectancy occurred mainly in the 20th century and, to be more exact, in the second half of the 20th century. One can see, for example, that life expectancy at birth for men went from 45.3 years in 1900 to 59.8 in 1945 , reaching 73.6 in 1994 . Life expectancy for women rose from 47.1 to 65.1 , and then to 81.8 in the same years, respectively.

${ }^{1}$ Some have evoked a possible «calendar effect» to claim that the present decline in the fertility rate revealed by the «snapshot method» could, in the long run, actually correspond to a smaller decrease of the fertility rate as estimated in terms of total descendants. It is true that if the calendar of births during the course of a life changes - in other words, if people have children later in the life cycle than before - the decline of the fertility rate, which is evaluated solely by the «snapshot method» and which compares the number of children born to the number of women of child-bearing age, would be temporarily amplified. Although such a calendar effect cannot be ignored, taking it into account does not significantly alter the real change in the fertility rate.

2 Keep in mind, even though this is stating the obvious, that the trend in life expectancy whether present or prospective - is a separate issue from that of the fertility rate. 


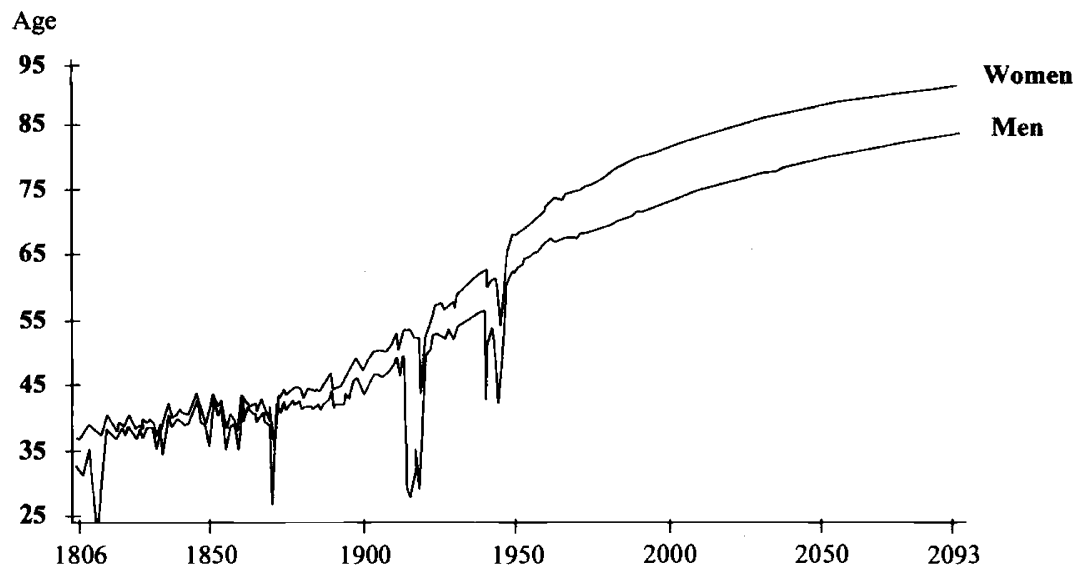

Source: Vallin, J., Risques, no. 5, April 1991.

We have stressed the converging patterns in fertility rates in the various developed countries. We can make the same observation with respect to the trend in mortality rates. As shown in Table 1, life expectancy has risen in all industrialized countries, reaching more or less identical levels today. This too is quite remarkable as these countries do not have the same income per capital, social security systems or even the same nutritional habits... Here again, there seems to be a phenomenon of convergence towards a mortality rate law that would apply to all the industrialized countries.

Table 1

\begin{tabular}{|l|c|c|c|c|}
\hline \multirow{2}{*}{$\begin{array}{l}\text { Life expectancy } \\
\text { and birth }\end{array}$} & \multicolumn{2}{|c|}{ Women } & \multicolumn{2}{c|}{ Men } \\
\cline { 2 - 5 } & 1950 & 1992 & 1950 & 1992 \\
\hline \multirow{2}{*}{ Germany } & 68,3 & 79,1 & 64,4 & 72,6 \\
France & 69,7 & 81,4 & 63,9 & 73,2 \\
Italy & 67,9 & $80,3 *$ & 64,3 & $73,6^{*}$ \\
United Kingdom & 71,3 & 79,0 & 66,5 & 73,6 \\
Switzerland & 71,3 & 81,3 & 66,9 & 74,5 \\
Spain & 64,3 & $80,5 *$ & 59,8 & $73,3^{*}$ \\
Japan & 60,8 & 81,7 & 57,5 & 79,9 \\
\hline
\end{tabular}

Source: Institut National d'Etudes Démographiques 
How will the mortality rate evolve over the decades to come? Here too, there are two schools of thought.

The first one maintains that only the well known phenomenon of the orthogonalization or squaring of the survival curves will continue. Survival rates at a given age are higher from one generation to another, but the maximum duration of life does not vary much, which means that, if the phenomenon were to continue, there would be an increasingly greater concentration of age groups at death (Curve 1, Chart 3 ).

\section{Chart 3: What will future trends in life expectancy be? Continued orthogonalization of survival curves or a significant shift in the maximum age at death?}

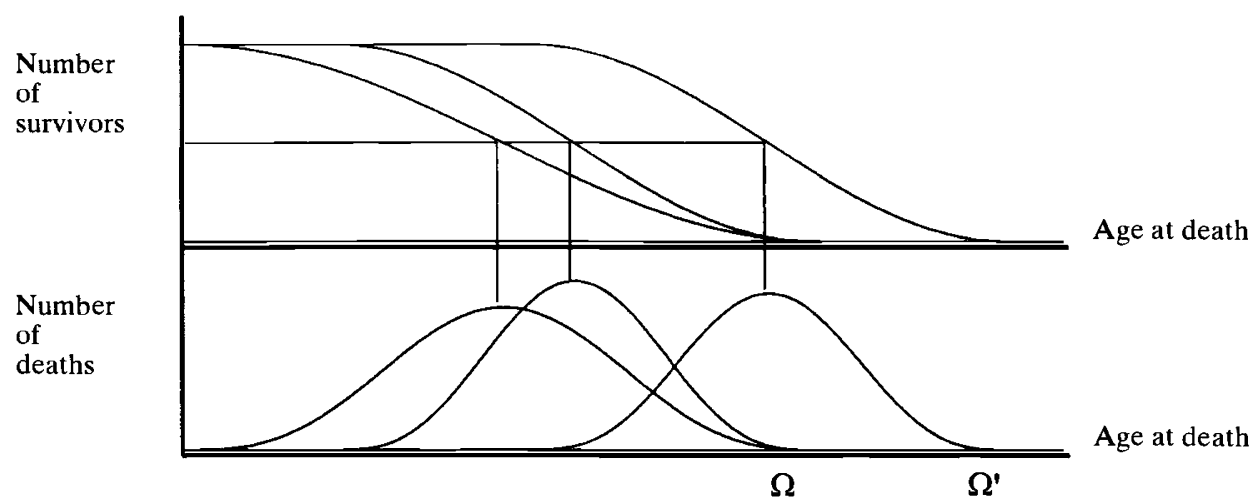

The second approach is based on the probable extension of the maximum duration of life - although we do not know when - as more significant discoveries are made in the treatment of cancer, cardiovascular diseases and other common deadly illnesses. This theory is reinforced further by the possibilities created through genetic therapies. In this case, the survival curve will shift again in the next century (Curve 2, Chart 3 ).

The majority of available population projections are based on the assumption that the phenomenon of the orthogonalization of the survival curves will continue, with this orthogonalization taking place at a faster or slower pace depending on the case. Of course, if the maximum duration of life were to be extended dramatically, these population projections would be refuted.

It is not an easy task to choose between these two theories, but it should be noted that the continuing trend of the orthogonalization of the survival curves is already bringing about an upheaval in the relative balance among age groups. We tend to think, however, that a sharp increase in the size of the cohorts of the very old is a real possibility. ${ }^{3}$

${ }^{3}$ For the anecdote, let us note that, at present, the maximum duration of life is increasing by one year every year. In effect, the oldest person alive today is Jeanne Calmant, who pushes back the limit with every birthday. 
We must stress the somewhat misleading nature of the «snapshot method» of calculating life expectancy on the basis of mortality rates observed at a given period. It is better to use the prospective life expectancy method, calculated generation by generation, and which takes into account the phenomenon of falling mortality rates. The difference between the two methods of measurement is significant (Chart 4), in the order of five years or more.

\section{Chart 4}
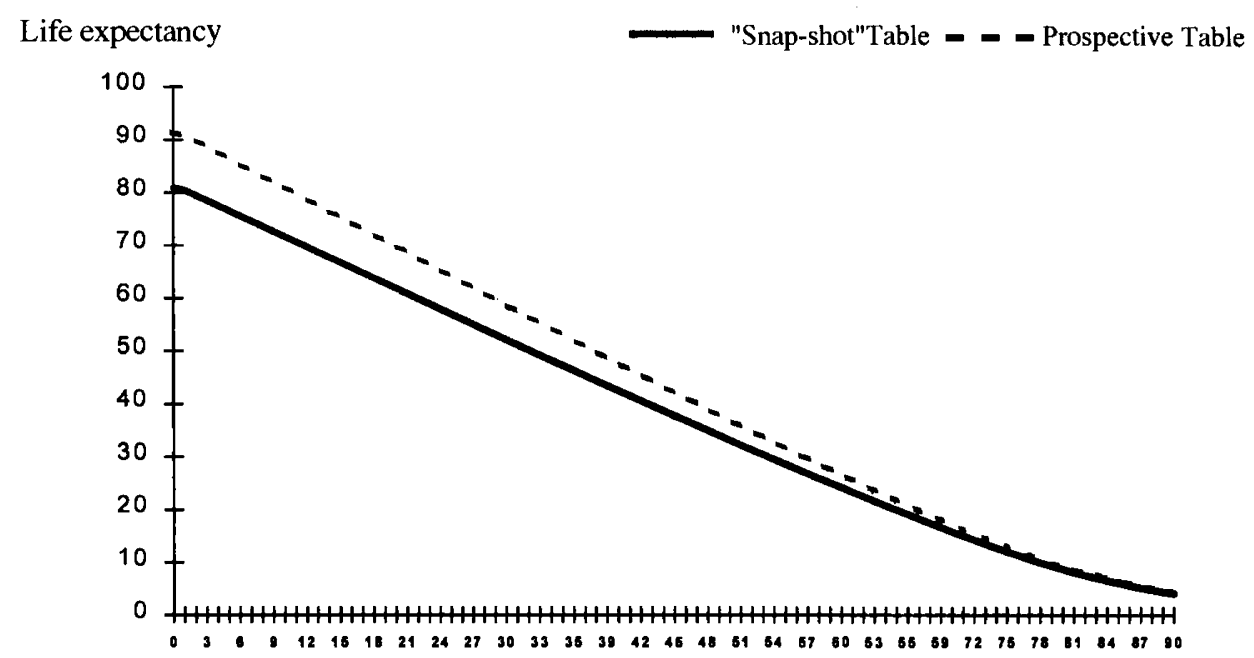

Age

Source: INSEE and GAP/FFSA

\subsection{Are migratory phenomena on the decline?}

The relative balance among age groups depends also on a third phenomenon: migratory flows. Whether we speak of emigration or immigration, migration flows directly affect the relative balance among age groups and, consequently, the demographic perspectives upon which the projections of intergenerational transfers are based. It is well known that it is hard to estimate the trend of migration movements. In fact, these depend on a great number of factors, in particular political ones, which are difficult to set up as models (Zimmermann (1995)).

In the case of emigration flows, factors which could modify the specific national propensities to emigrate are not obvious. In the industrialized countries, the propensity to emigrate is nowadays very low. This has been the case for more than two centuries in France. In northern European countries, emigration flows have also decreased in the course of history. This is also true today for southern European countries. Even though it is plausible 
that European integration should result in greater intra-European population flows than in the past, this phenomenon will nevertheless probably remain limited. As for emigration of the French population outside Europe, this too will probably remain limited. A nuance is called for here. If aging (see infra) were to create too great a tax and social burden for the active population, this part of the population might be inclined to «eliminate» the burden by emigrating to countries with a young demographic structure and hence with lower social charges (this would be a sort of international «Tiebout effect», with populations moving from zones of high-pressure taxation and social charges to low-pressure zones).

With respect to immigration flows, Europe changed its policy in 1973 (Zimmermann (1995)) and the migration flows have slowed considerably. In this case, it is not so much the desire of foreigners to immigrate into Europe which has diminished, but rather Europe's desire to accept them.

While avoiding rash projections on this subject, we can still put forward the idea that a change of immigration policy should not be dismissed if the present trend in fertility and mortality rates continues, thus resulting in an intolerable disparity in the relative balance among age groups. It is also interesting to note that there is often much talk of using immigration as a means, among others, of remedying the effects of population aging on the payas-you-go pension schemes.

\subsection{The relative balance among coexisting generations is going to change substantially in the decades to come.}

With the stagnation of the fertility rate, the increase in survival rates, and the probable reduction of migration flows, the age structure of European populations is going to evolve substantially. Without going into a long discussion about the validity of the assumptions underpinning available projections, we can simply refer to the latest INSEE ${ }^{4}$ studies to highlight the magnitude of the upheaval in the age pyramid which will take place over the decades to come in the case of France.

Charts 5, 6 and 7 give the age pyramids for 1994, 2020 and 2050, according to three different hypotheses on the fertility rate: 1.5 children per woman, 1.8 children per woman and 2.1 children per woman. These charts alone show the considerable upheaval in age groups due to the double effect of fertility rate and mortality rate variations. The most striking phenomenon is indeed the relative increase in the size of the older generations by the turn of the next century, an increase which will have a real impact on all mechanisms for age-related redistribution of resources.

When considering the aging of populations, the variation in fertility rates is often presented as the most important factor, followed by variations in mortality rates. Computations done in the case of France show that over a 70-year period of time, the variations in the mortality rate accounted for almost two-thirds of aging, while variations in the fertility rate accounted for one third (Blanchet and Kessler (1991)).

\footnotetext{
${ }^{4}$ Economie et Statistiques, No. 274 (1994-4), p. 20.
} 
Chart 5: Breakdown of the French population by sex and age as of 1 January 1994

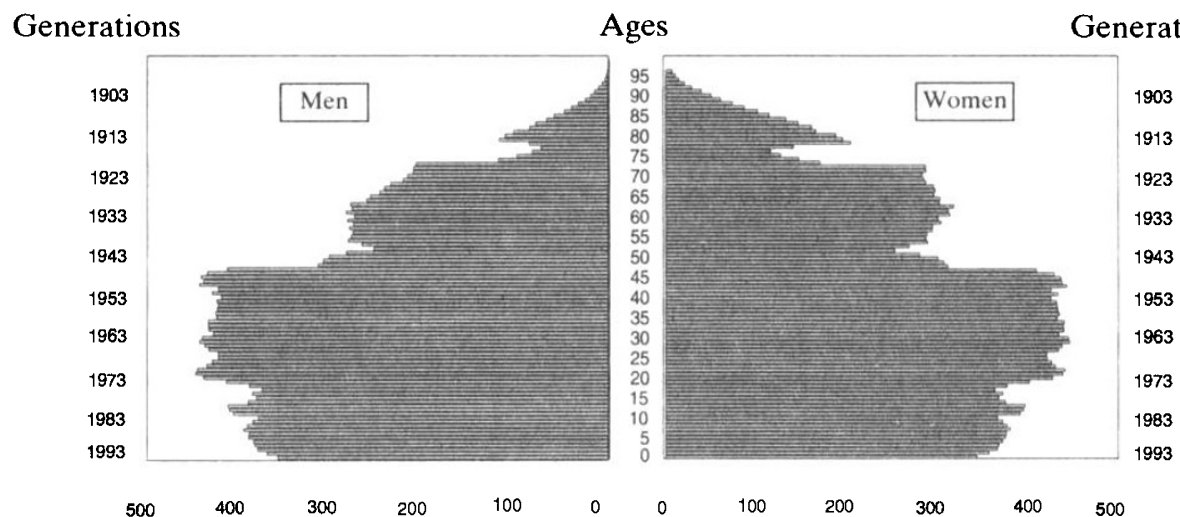

Chart 6: Breakdown of the French population by sex and age as of 1 January 2020

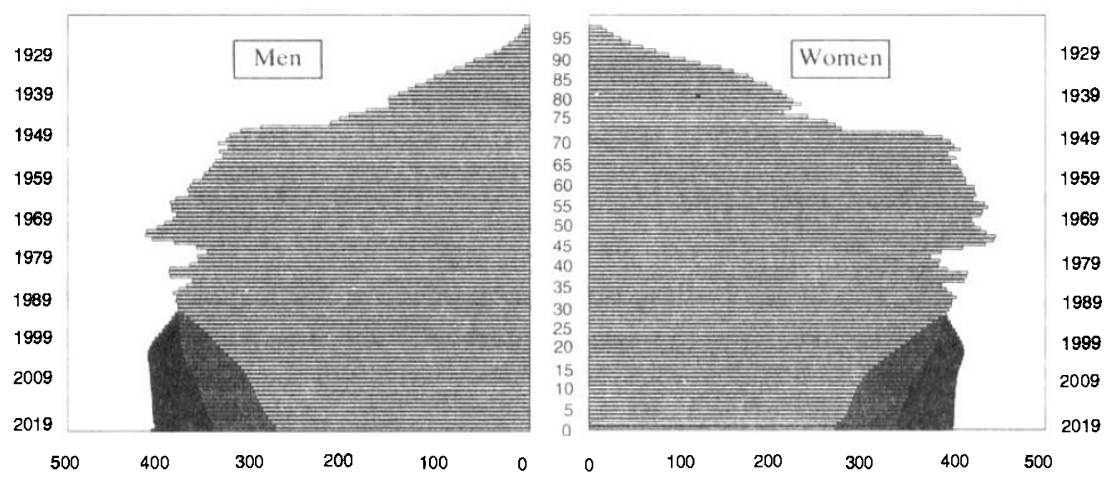

Chart 7: Breakdown of the French population by sex and age as of 1 January 2050

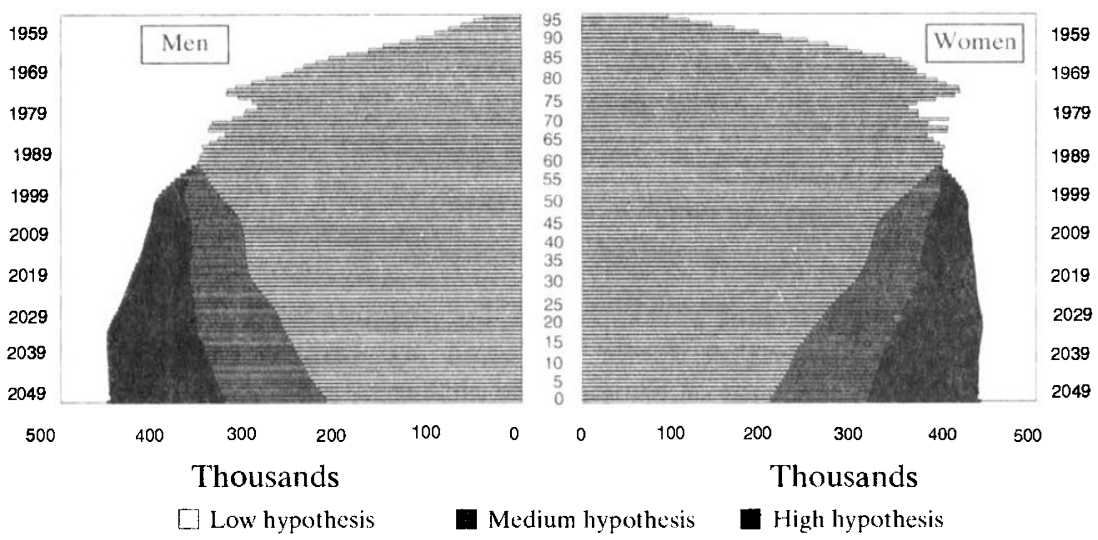

Source: INSEE 
To illustrate this impact, Chart 8 shows the net change in the population aged 60 and over, from now to 2050 . It can be seen that, for the next twenty years, the net annual increase in the number of persons over 60 years of age will be between 250,000 and 350,000 .

Chart 8: Net variation of the population over 60 years of age

In thousands

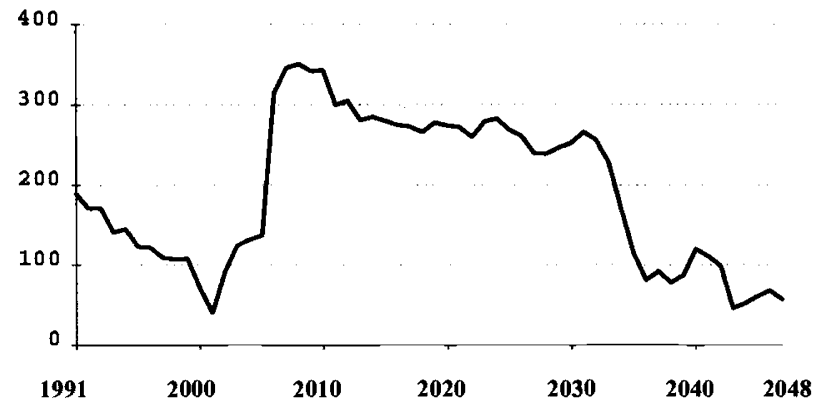

Source: INSEE

Available population projections for the first half of the 21st century show that all industrialized countries will experience similar developments. The relative importance of aging will vary however: countries that have already experienced the aging phenomenon, like the United Kingdom, will tend to age less in the future than countries in which there was a very strong post-war baby boom. Table 2 recalls the population projections made by the O.E.C.D..

Table 2: Population (in millions) and proportion of the population of 65 years of age or more (in \%)

JAPAN

Population in millions

Proportion over 65 and more

\begin{tabular}{|c|c|c|c|c|c|c|}
\hline 50 & 1980 & 1990 & 2000 & 2020 & 2040 & 2050 \\
\hline $\begin{array}{r}83,66 \\
5,0 \%\end{array}$ & 117,06 & $\begin{array}{r}122,79 \\
\end{array}$ & $\begin{array}{r}127,35 \\
\end{array}$ & $\begin{array}{r}125,95 \\
2000 \%\end{array}$ & $\begin{array}{r}119,85 \\
270 \%\end{array}$ & \\
\hline
\end{tabular}

\section{FRANCE}

Population in millions

Proportion over 65 and more

UNITED KINGDOM

Population in millions

Proportion over 65 and more

GERMANY

Population in millions

Proportion over 65 and more

\section{ITALY}

Population in millions

Proportion over 65 and more

SWITZERLAND

Population in millions

Proportion over 65 and more

USA

Population in millions

Proportion over 65 and more

Source : O.E.C.D.

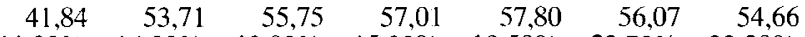

$\begin{array}{lllllll}11.30 \% & 14.00 \% & 13.80 \% & 15.30 \% & 19.50 \% & 22.70 \% & 22.30 \%\end{array}$

$\begin{array}{lllllll}50,37 & 56,01 & 56,47 & 57,15 & 58,34 & 57,66 & 56,75\end{array}$

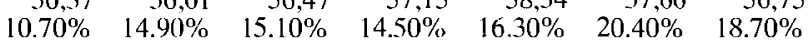

$\begin{array}{rrrrrrr}49,98 & 61,57 & 60,95 & 59,62 & 52,67 & 45,30 & 41,84 \\ 9.30 \% & 15.50 \% & 15.50 \% & 17.10 \% & 21.70 \% & 27.60 \% & 24.50 \% \\ & & & & & & \\ 47,11 & 57,07 & 57,10 & 56,56 & 53,25 & 48,34 & 45,57 \\ 8.00 \% & 13.40 \% & 13.80 \% & 15.30 \% & 19.40 \% & 24.20 \% & 22.60 \% \\ & & & & & & \\ 4,69 & 6,33 & 6,50 & 6,55 & 6,34 & 5,68 & 5,34 \\ 9.60 \% & 13.80 \% & 14.80 \% & 16.70 \% & 24.40 \% & 28.30 \% & 26.30 \% \\ & & & & & & \\ 152,27 & 227,74 & 248,54 & 265,40 & 293,51 & 309,41 & 314,47 \\ 8.10 \% & 11.30 \% & 12.20 \% & 12.10 \% & 16.20 \% & 19.80 \% & 19.30 \%\end{array}$


How can one argue that such an upheaval in the relative balance among age groups will have no economic and social effects?

\section{The aging of the population will affect all intergenerational transfers.}

\subsection{The wide diversity of intergenerational transfers}

In our society, there is a permanent overlapping of a great many forms of exchange and transfers between the coexisting generations. They can be private, in which case they are mainly organized within the family, or they can be public, in which case they are subject to decisions made by public authorities. They may be ascending, i. e. going from the children to their parents (or from young people to older people) or they may be descending. They may also take the form of cash or time, or they may be exchanges in kind. Table 3 provides a limited list of the main types with some estimates for the French case.

Table 3

\begin{tabular}{|c|c|c|c|c|}
\hline Type & \multicolumn{2}{|c|}{ Private, within the family } & \multicolumn{2}{|c|}{$\begin{array}{l}\text { Public, organized by the State } \\
\text { or local authorities }\end{array}$} \\
\hline Direction & Descending & Ascending & Descending & Ascending \\
\hline \multirow{6}{*}{ Cash transfers } & Inheritance: $100\left(^{*}\right)$ & & & $\begin{array}{l}\text { Increase in public } \\
\text { debt }(-)\end{array}$ \\
\hline & $\begin{array}{l}\text { Inter vivos } \\
\text { bequests : } 28\left(^{*}\right)\end{array}$ & $\begin{array}{l}\text { Inter vivos } \\
\text { bequests (rare) }\end{array}$ & & $\begin{array}{l}\text { Public pensions: } \\
647(* *)\end{array}$ \\
\hline & $\begin{array}{l}\text { Financial aid:? } \\
\text { (regular payments, } \\
\text { assistance with pur- } \\
\text { chase of home) }\end{array}$ & $\begin{array}{l}\text { Financial aid: } \\
\text { (regular payments, } \\
\text { payment for } \\
\text { domestic } \\
\text { assistance) } \\
\end{array}$ & & \\
\hline & & & $\begin{array}{l}\text { Family allowances: } \\
93(* *)\end{array}$ & $\begin{array}{l}\text { Reimbursement of } \\
\text { health expenses }(-)\end{array}$ \\
\hline & $\begin{array}{l}\text { Low-interest } \\
\text { loans:? }\end{array}$ & & $\begin{array}{l}\text { Unemployment } \\
\text { benefits for the } \\
\text { young:? }\end{array}$ & $\begin{array}{l}\text { Early retirement } \\
\text { and unemployment } \\
\text { benefits for the } \\
\text { elderly:? }\end{array}$ \\
\hline & $\begin{array}{l}\text { Educational } \\
\text { expenses: ? }\end{array}$ & & $\begin{array}{l}\text { Educational expen- } \\
\text { ditures: } 335(* *) \\
\text { (including } \\
\text { scholarships...) }\end{array}$ & \\
\hline \multirow{4}{*}{$\begin{array}{l}\text { Transfers in the } \\
\text { form of time or in } \\
\text { kind }\end{array}$} & $\begin{array}{l}\text { Assistance in kind:? } \\
\text { (free lodgings...) }\end{array}$ & $\begin{array}{l}\text { Care or services } \\
\text { provided for aged, } \\
\text { dependent parents }\end{array}$ & Day care:? & Health care:? \\
\hline & & & & Retirement homes:? \\
\hline & Educational time:? & & & \\
\hline & $\begin{array}{l}\text { Babysitting for } \\
\text { grandchildren:? }\end{array}$ & & & \\
\hline
\end{tabular}

The question marks (?) indicate unquantified amounts.

$(*)$ billions of French francs in $1984 \quad(* *)$ billions of French francs in 1988 or 1989

(-) The fluctuation of public debt was 87 billion French francs in 1987; only a part of it represents transfers between generations.

(-) Amount of reimbursements of health expenses: 383 billion French francs in 1988, of which more than $50 \%$ to people over 60 .

Source: KESSLER, Denis, MASSON, André and PESTIEAU, Pierre, Economie et prévision, No. 100-101, 1991 4/5. 
What can be observed when an attempt is made to put a figure on these various intergenerational transfers?

First, public and social transfers tend to go back up the generation chain, in other words to go from the young, active generations to the older ones. This is obviously the case of pay-as-you-go pension schemes, in which resources collected from the active population are immediately transferred for exclusive use of the inactive population. Given the volume of pensions paid today - somewhere in the region of 850 billion French francs, representing $12.5 \%$ of GDP - the latter represent the main intergenerational transfer. Moreover, this transfer has steadily increased over the last 50 years. It should be kept in mind that in the sixties, the volume of retirement pensions stood at around $6 \%$ of GDP.

The ascending generational direction of public and social transfers can also be seen in health insurance expenditures, although to a lesser extent. Given the distribution of health expenses by age (Chart 9), it is clear that a large share of health insurance transfers benefits the elderly. Since it is mainly the active population from whom health insurance contributions are collected, it can be concluded that this is an ascending social transfer.

Chart 9: Distribution of health expenses by age in France: Amount of annual average reimbursement per beneficiary (combined expenditures 1992)

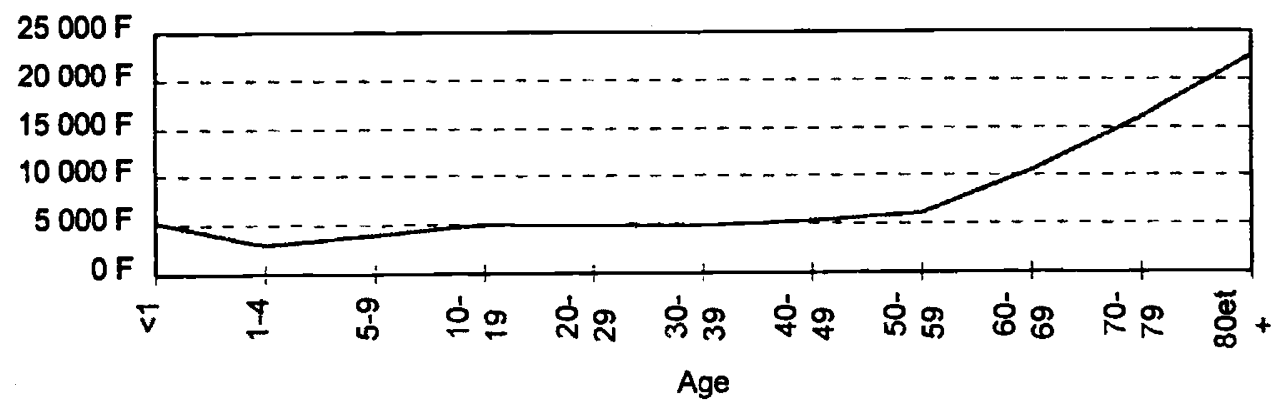

Source: CNAM, March 1995.

It must be emphasized that this transfer has also increased due to the combined effects of two factors: first, the rise in health insurance expenses (medical consumption today stands at around 650 billion French francs, or $8.8 \%$ of GDP), and second, the growing concentration of health expenditures for the benefit of the older generations (Chart 10 clearly shows the growth of health expenses of the elderly between 1960 and 1991). It should be noted that the latter trend is not merely a mechanical phenomenon, but one which reflects political choices. 
Chart 10: Health expenses in France by age

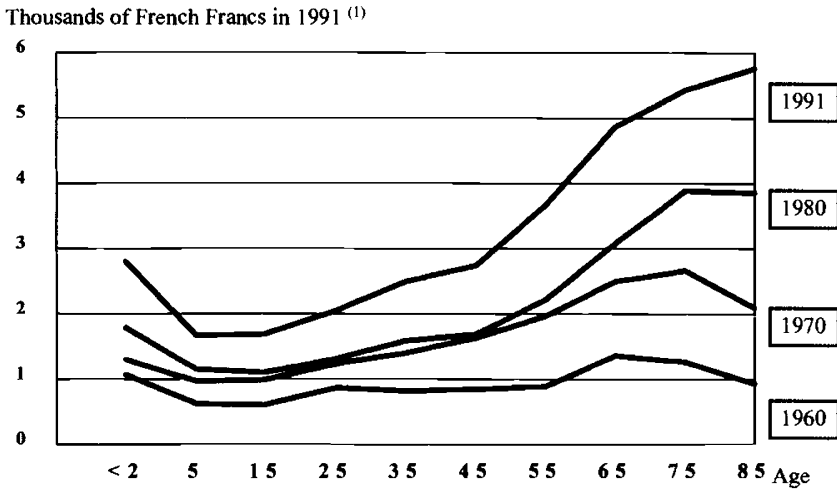

(1): Partial cost of medical, prescription drug and dental care per person per annum Source: Credes - 1995

If we leave the social sphere and look at the areas for which the State is directly responsible, the increasing burden of public debt must be mentioned. When a State's finances are in deficit at a given point in time because it does not collect the requisite resources to finance its expenditures, it places a «public debt burden» on its future generations. Indeed, this means that future generations of taxpayers will be called upon to reimburse the public debt. This will reduce their disposable income. Naturally, this line of reasoning must be tempered by the fact that some public expenditures are allocated to lasting investments from which future generations will also benefit.

Nevertheless, the public debt has risen dramatically over the past few years, as public deficits deepened (Chart 11). Today, the public debt is estimated at more than 3,500 billion French Francs, i.e., almost one half of GDP. In 1995, the public debt per employed Frenchman stood at 165,000 French francs.

\section{Chart 11: Public debt and deficit in France as a \% of GDP}

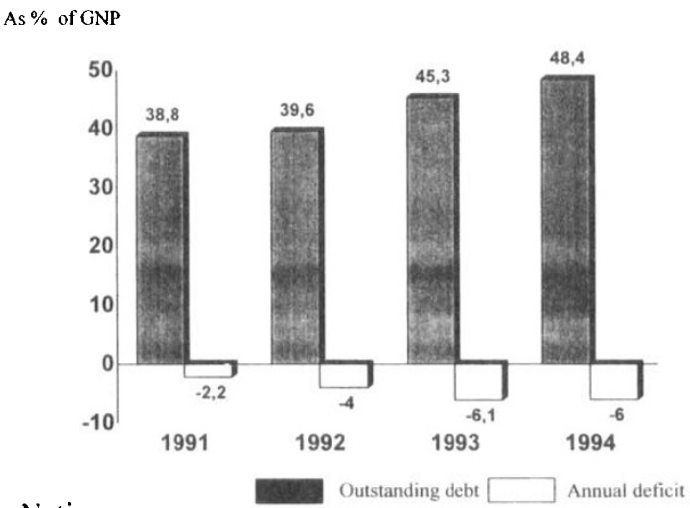

Source: Comptes de la Nation 
However, the State also implements transfers which go down the generation chain, primarily education and training expenditures. These transfers, amounting to 300 billion French francs, represent about $4 \%$ of GDP. Because they are financed through the general budget, the «burden» of these transfers is spread out over the entire population, in contrast to pensions and health insurance expenditures, which are financed through payroll taxes.

To this must be added other public expenditures such as family allowances, of around 60 billion French francs, financed by payroll taxes, but which correspond more to a redistribution of resources within one generation - among active members of the population than to a redistribution of resources between generations.

A more detailed study of the distribution by age group and by generation of both resources and public and social expenditures is obviously necessary in order to better define the magnitude and direction of the redistribution implemented by the State. With regard to expenditures, we can quote Buiter (1995) who stated, in a recent contribution, that «not all generations alive during a period benefit equally from government consumption during that period».5 However, such a study would certainly not contradict the argument that, today, the net balance of public and social transfers largely benefits the older generations. ${ }^{6}$

With respect to private transfers, one notes that most of them go down the generation chain. This is the case of private expenditures on education and training, and also of parental assistance to children. It is also the case of all inter vivos bequests and inheritances. However, the amount of these transfers, which are more difficult to quantify, appears to be much less than that of public and social transfers. Obviously, the time and attention (non-monetary variables) which the older generations give to the younger ones would have to be added, in order to have a more precise idea of the size and direction of private transfers between coexisting or successive generations.

According to available figures, private intergenerational transfers are on the rise. This seems to be the case for assistance, inheritances and inter vivos bequests. This may be explained by the relative enrichment over the last few decades of the older generations, who were able to accumulate personal wealth more easily thanks to the support provided by social and public transfer mechanisms. When someone benefits from unanticipated

${ }^{5}$ And Buiter adds, «old age pensioners do not benefit equally from free rock concerts as do teenagers. Education (which has a consumption component as well as a human capital formation component) likewise benefits the young more than the old. Expenditures on law and order bestow benefits that are increasing with one's level of non-human wealth. (...) The benefits derived from national defence are also likely to be increasing with one's level of non-human resources. Benches in public parks are mostly appreciated by the still mobile old and by parents of very young children. Teenagers and young adults prefer soccer pitches and ice rinks. Health expenditures benefit mostly the very young and the very old. Free condoms benefit primarily the sexually active age groups».

${ }^{6}$ It should be pointed out that in France the major part of social expenditures is financed through payroll taxes and that it is mainly the employed population which is affected. In other EU countries, i.e. those which have opted for a distributive rather than a commutative philosophy, such as the UK and Denmark, social expenditures are covered by the general budget of the State. The concentration of social expenditures by age groups is therefore much lower since, by definition, general taxation has a wider base than payroll taxes. 
resources stemming from public transfer mechanisms, he can keep previously accumulated wealth throughout his lifetime. Moreover, this wealth was increased by substantial asset revaluations during the eighties and by the shift to a positive real rate of return on savings. This phenomenon has been observed in most, if not all, industrialized countries.

If we add together all public and private intergenerational transfers, we will most certainly obtain a balance in favour of the older generations. This balance is mainly the result of collective intervention - the State, of course, but also the «social partners» (labour unions and management) - which, deliberately or not, appears to have generously favoured the older generations during the last few decades by organizing a massive, compulsory transfer of resources towards the top of the age pyramid (Kessler (1990)).

Many facts bear witness to the intensity of these transfers. Let us take two examples: (i) the standard of living of older people expressed in units of consumption is, on average, higher than that of the working population, and (ii) the average age of consumers is substantially higher than that of producers. The State, in the wide sense of the term, has become the umpire between generations. It has chosen to favour the older generations. Is this a conscious choice? Is it a voluntary one? Is it a responsible decision? Above all, is it sustainable and can it last in the face of an accelerated aging of the population?

\subsection{The foundations of intergenerational transfers}

The underlying motives of private transfers between generations must be distinguished from those of public transfers between generations. Indeed, the reasons which can be evoked to explain the direction and the size of transfers between generations are very different, depending on whether the said transfers are relative to the private sector (households or businesses) or the public sector (the State through its budget, or management and labour through social insurance schemes).

\subsubsection{The underlying motives of private intergenerational transfers}

Over the past twenty years, a whole series of research projects have been carried out on the underlying motives of private intergenerational transfers. For households, this refers mainly to assistance and provision of care or services as regards ascending transfers, and to inter vivos bequests, inheritances and educational expenses as regards descending transfers.

Without going into all of the arguments put forward by economists and sociologists, we can note that the underlying motives of private transfers effected by households fall under at least four, perhaps even five, paradigms:

- The unawareness or uncertainty paradigm: many transfers are involuntary. This is true, for example, of inheritances. Since they do not know when they will die, individuals involuntarily leave inheritances which benefit the younger generations. Life duration still remains uncertain today, as can be seen from the variance of age distribution at death, even though the phenomenon of the orthogonalization of the survival curves mentioned supra reduces this variance generation after generation.

- The paternalism paradigm: according to this paradigm, the transfer of resources to other generations is status-enhancing, and allows individuals to demonstrate their authority. 
Bequeathing and transferring in this case increases the utility of the donor generations (as in King Lear). It should be stressed that under this paradigm, the transfers reflect the will of the donor generation to influence the behaviour of the receiving generations.

- The altruism paradigm: in this case, individuals care about the welfare of other generations. Through the transfer of resources, they try to equalize the standard of living from one generation to another. Their choices take into account the utility of the other generations and, if the gap in the level of well-being between generations widens, compensatory transfers are made. If altruism were the prima ratio for intergenerational transfers, the frequent use of the term «solidarity between generations» would be legitimate.

- The strategy paradigm: in this case, the various generations are involved in relations of a strategic nature. For example, the older generations, in seeking to obtain care and time from the younger ones, exercise a sort of blackmail. The younger generations, interested in obtaining the wealth of the older ones, become involved in complex relationships in which each party tries to turn the situation to its advantage. Taken to extremes, this paradigm leads to the case where each generation seeks to give the minimum in order to receive the maximum from the other generations, and a certain generational selfishness arises. It is easy to understand the stakes that political power represents in this context. In view of the role of the State, the objective is to weigh on the choices made in order to obtain the maximum level of resources. Some scholars have not hesitated to set up politico-economic models to find the optimal voting strategy for obtaining the sharing out of resources in favour of a particular age group.

- The fifth paradigm is that of market relations between the generations. Even if the conditions of «exchange» are not obvious straightaway, it could be considered that certain transfers, seemingly made without any compensatory motive, are in fact the price paid in exchange for services rendered previously or to be rendered later. Thus, educational expenses, for instance, would be the price to pay in order to have a retirement pension later on. Another example would be inheritance: this would be the price to pay for being looked after all one's life by one's children. These are exchanges between the generations, but of an original nature, different from those usually seen on the various markets.

In reality, private transfers between generations are surely a subtle mix of all of these paradigms, i.e. unawareness, paternalism, altruism, strategy and market exchanges.

But other private transfers are carried out by businesses. These transfers are the result of provisions such as seniority or severance pay or indeed private pension plans. Thus for some scholars, there is a discrepancy between the evolution of the productivity of individuals during their lifetime and the evolution of salaries (Lazear (1979), Blanchet and Kessler (1990)). At the start of a career, work productivity is greater than salary earned, whereas the situation is reversed at the end of a career. Hence, when seniority rules are applied, there is a substantial transfer of resources between young active people and older active people. This transfer is made that much easier when the number of young active people is high and the number of older active people is limited. The entire post-war period has been characterized by this situation because of steady growth in the working population. Consequently, the seniority rules in force, whether de jure or de facto, resulted in sub- 
stantial transfers. The reversal of the demographic situation is likely to make these implicit transfers more difficult, insofar as the slowdown in hiring and the aging of the working population are gradually limiting the possibility of maintaining generous seniority rules and pro-active policies for managing careers and promotions.

\subsubsection{The underlying motives of public intergenerational transfers}

The underlying motives of public intergenerational transfers are to be found first and foremost in the idea that the spontaneous distribution of resources between the generations - such as that which would result from giving free rein to behaviour and to the markets - is not optimal, neither from the point of view of efficiency nor from that of equity. Hence, State intervention is considered necessary to effect transfers of resources in order to correct the primary distribution of resources and standards of living. Naturally, all of these forms of redistribution pass through the filter of politics.

We can illustrate the comment concerning inefficiency of the primary distribution of revenue by examining the issue of public spending on education. If parents do not invest sufficiently in the education of their children, the human capital accumulation rate will be insufficient and economic growth will slow down in the long term. It suffices to observe that the social rate of return on educational expenditures is greater, on average, than the private rate of return; or, to take another example, that the return hoped for, or perceived, by families from investment in education is lower than actual returns. Consequently, public spending on education represents, in a sense, a compulsory investment from which the whole community will benefit, both current and coming generations. However, this public expenditure can also be justified by the fact that certain households do not possess the necessary resources to finance educational expenses. In this case, it is the principle of equity which justifies this public intervention of compulsory resource transfers between generations.

An analogous form of reasoning can be outlined with regard to retirement-based transfers (Kessler (1989), Bourguignon and Kessler (1994)). If households underestimate their life duration and its lengthening over time, or if they save insufficiently for their old age because they have a discount rate that is too high, they risk ending up in a difficult situation, thus necessitating intervention by the authorities due to the «social externalities» that such a situation would generate. In this case, the State would be led to act in a curative capacity, whereas imposing compulsory coverage allows it to act in a preventive manner.

In the case of health insurance coverage, the reasoning is also quite similar. Households do not spontaneously see the utility of health care and do not turn spontaneously to the private insurance market to protect themselves from the consequences of illness (Arrow (1963)). Here again, compulsory coverage for all households would be optimal. Moreover, it would eliminate the well-known phenomenon of adverse selection specific to the free insurance market.

Since the State, for obvious reasons of lack of information, does not have the means to distinguish between those households which would spontaneously adopt an optimal behaviour from the rest, it is led to implement collective mechanisms with compulsory coverage. 
Hence State intervention for the sharing out of resources between coexisting age groups is based on the following paradigms:

- The asymmetrical information paradigm: Individuals, or a certain proportion of them, do not dispose of the necessary information to make optimal choices. Asymmetrical information can generally explain some of the dysfunctions in insurance markets. Moreover, the State does not have the information needed to target its intervention (or the requisite information would be too costly to obtain).

- The preference-for-the-present paradigm: In this case, individuals are assumed to be impatient and, consequently, their time horizon is limited. This means that they do not pay sufficient attention to events that would occur beyond their time horizon. Thus they would neglect, for instance, the educational expenses of their children by underestimating the long-term profitability of this type of investment in education. Income derived from this investment would be discounted at too high a rate. The State has a lower discount rate, corresponding to the maximization of collective utility, and it imposes certain choices on the economic actors. ${ }^{7}$

- The insufficient-risk-aversion paradigm: Even if a perfect knowledge of risk is assumed, certain individuals might not seek to protect themselves adequately, through incompetence or lack of foresight. They would overexpose themselves and their relatives to risk. If the risk materializes, the individuals might end up in a situation calling for intervention by the public authorities.

- The imperfection-of-the-markets paradigm: In this case, the markets are imperfect and do not allow people to protect themselves in the most optimal way. Implementation of public programs is hence justified. The classic example is the implementation of pay-asyou-go social security systems to finance pensions: such systems are supposed to be the response to the failures of capital markets.

Explanations concerning public debt differ from those which may be put forward for social insurance mechanisms and public spending on education. For some, the State issues public debt, following the example of other economic agents, to finance its investment spending which will be spread over several decades or several generations. ${ }^{8}$ For others, the State issues debt for reasons of counter-cyclical economic adjustment, i.e. debt swells during periods of recession and is reimbursed during periods of expansion. For yet others, the increase in debt reflects exceptional government spending (wars, for example) the cost of which is spread over several generations. ${ }^{9}$

This brief and non-exhaustive discussion of the underlying motives of private and public intergenerational transfers shows that the latter are based on very different principles. For each transfer considered individually, several explanations can always be put forward. Several questions may be raised in this regard:

\footnotetext{
7 This argument is often evoked to explain the mechanisms of «forced savings» that compulsory pension plans represent.

${ }^{8}$ In this case, there are active people to pick up the State's debt, and the generations who "inherit» the debt to be reimbursed also «inherit» the public assets financed by the debt.

'One cannot totally dismiss the idea that the public deficit is sometimes the result of lax government management!
} 
Are intergenerational transfers implemented consciously or voluntarily, or are they the result of a whole series of uncoordinated private and public decisions?

Do intergenerational transfers result in the equalization of the levels of well-being from one generation to another?

Are intergenerational transfers aimed mainly at obtaining a more efficient allocation of resources than that which results from the primary distribution of resources?

Do intergenerational transfers interact with each other, i.e. public transfers supplant or supplement private ones, descending transfers compensate (or not) ascending transfers?

Whatever the answers to these questions, all intergenerational transfers will be affected by the aging of the population.

\subsection{The aging of the population will affect all intergenerational transfers.}

The shift in the relative balance among age groups will, in the first place, affect the primary distribution of resources by age. This will be reflected by substantial changes in the magnitude of private and public intergenerational transfers.

The allocation of available resources - in the broad sense of the word - among age groups is based on very diverse phenomena. We shall discuss, successively, primary income and wealth distributions.

\subsubsection{Aging and primary income distribution}

Activity is no doubt the paramount phenomenon, since it is that which determines the primary distribution of resources among the age groups. We know that activity rates have evolved over the past thirty years, with a levelling out of male activity rates both at the beginning of adult life (studies lasting longer) and as of age 50 (phenomenon of early retirement and lowering of the retirement age). Hence there is a pronounced concentration of the distribution of primary income, for men, based on age. The distribution is certainly more concentrated in France than in other countries. Indeed, average activity rates are low (one French person out of two participates today in a productive activity), but they are particularly low in France for those over age 55. By contrast, there has been a very significant rise in activity rates for women, which are approaching male rates.

Thus, the bulk of primary income has become heavily concentrated around a fraction of the population, and this phenomenon is all the more evident today if one looks not at activity rates but at the number of people who are employed. Indeed, unemployment, which is particularly high at the beginning and the end of a career, is compressing even further the age-based distribution of income.

If we add to this the fact that, as a general rule, income from work is also an increasing function of age ${ }^{10}$ the concentration of primary income according to age is still greater than that which can be assumed from the mere distribution of activity rates.

${ }^{10}$ Mainly, but not solely, because of seniority rules. 
The aging of the population should result in a steady rise in the average age of the "producers». From the year 2005, using realistic assumptions on the evolution of activity rates, there will most probably be a decrease in the active population, as the full generations of the post-war baby boom leave the labour force. This is shown in Chart 12 . Naturally, this decrease will be of a greater or lesser magnitude, depending on the parameters chosen. However, unless there is a massive wave of immigration and a huge rise in the retirement age, it seems realistic to assume that the active population will begin to decrease from that date. The employed population could increase, to the extent that the scarcity of job seekers may help to diminish the rate of unemployment.

Chart 12: Proportion of population of active age to the total population

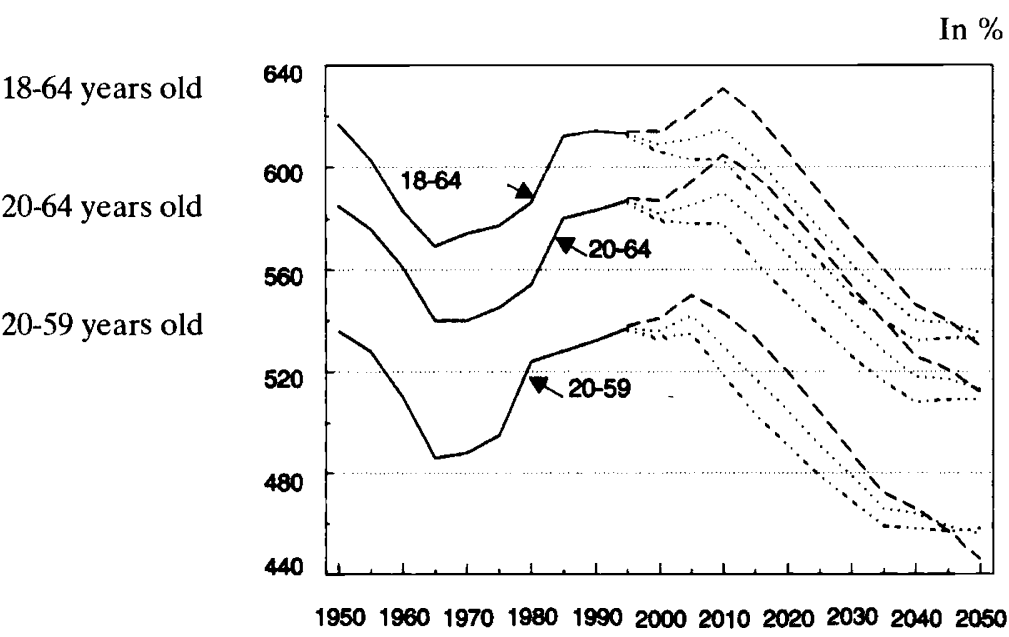

Source: INSEE

This aging of the active population raises three questions:

- The evolution of net income: The distribution of net income according to age, after taxes and other withholdings, will depend on the fiscal and social decisions made during the years to come. In France for instance, a shift in the financing of social security from the current system of salary-based contributions to a system of income taxation would profoundly modify the distribution of net income.

- The evolution of productivity: Will the ineluctable modification of the age pyramid of «producers» affect average productivity? Even assuming a relatively strong variation of productivity according to age, it would seem that variations in average productivity caused by the aging of the active population would remain relatively modest (Blanchet and Kessler (1990)).

- The evolution of seniority rules: The role of age in the distribution of salaries will, no doubt, change greatly. It would appear that the mechanism by which a transfer is made from young salaried people (paid below their level of productivity) to older salaried 
people (paid above their level of productivity) will be reviewed gradually as the agerelated structure of the active population loses its shape. Seniority rules are easy to implement during periods when the active population is young, but very expensive during periods of aging. ${ }^{11}$ Consequently seniority rights will probably lose their value in the same way (and for the same basic reason) as retirement rights. From the same viewpoint, career advancement will be less rapid in the decades to come than it was in the past.

\subsubsection{Savings, inheritance and aging}

What is the starting point? It is that of an important concentration of wealth according to age. This can be explained by the traditional effect of age - wealth is an accumulation variable - but also by a range of generational effects. Wealth is, at present, mainly concentrated at the top of the age pyramid.

Indeed the current older generations have been particularly privileged as regards wealth accumulation. Throughout the eighties, older people benefited from the spectacular appreciation of the value of personal assets, due to the rise in stock prices and real estate. Since they held a major share of yield-bearing assets, their investment income increased greatly. At the same time, retirement rights for successive generations reaching the age of cessation of activity have become greater and greater, and pensions have been constantly over-indexed. Consequently, older people have not had to sell their personal assets because they have enough regular income to allow them to finance their period of inactivity. Furthermore, there was less incentive to save than previously, since collective welfare programs - in the form of social transfers - substituted for individual welfare arrangements in the form of savings.

On the other hand, the younger generations were much less favoured by this period. They have been hard hit by unemployment. High interest rates have discouraged them from purchasing a home, a rising share of their income is allocated to housing, and a substantial portion of their monthly payments consists in the payment of interest rather than repayment of principal. The uninterrupted increase in social and fiscal withholdings has restricted the increase in their disposable income which was already affected by a slowing down in the growth of purchasing power. It is therefore not surprising that their rate of savings has stagnated or decreased.

Over the last fifteen years in a country such as France, the household savings rate has gradually declined by one third. This movement has been general throughout Europe, with the notable exception of the United Kingdom. Today, the savings rate represents about $12 \%$ of disposable income whereas it was hovering around $20 \%$ at the end of the seventies. At the time, savings - i.e. the non-consumed share of income - represented the main source of accumulation of wealth. This savings rate includes repayment of loans but not the interest charges which, from an accounting point of view, corresponds to «consumption». Households became wealthy mainly by postponing consumption. Moreover, some of them pocketed a part of the inflationist transfers resulting from the repayment of loans in

${ }^{11}$ In reality, the review of the rules of automatic seniority is already in progress today. Moreover, the development of early retirement mechanisms and the lowering of the retirement age have reduced the value of working at an advanced age. 
devalued money, to the detriment of other households which were subject to an inflationist drain on their income.

What will be the effect of aging on savings and the distribution of wealth?

- Savings and aging: The most common assumption is that the savings rate will rise over the coming years, as the full post-war generations come of saving age. Worried by the prospects for the pay-as-you-go pension schemes, the so-called baby boom generations would make a substantial savings effort to accumulate wealth which, either through income earned on it or through realization of the assets composing it, would allow them to maintain their standard of living after ceasing their activity. This increase in the household savings rate would be followed in about thirty years by a sharp drop. But the idea can also be put forward that the drop in the savings rate expresses a change in values, since the present active generations have a lower propensity for accumulating wealth than their elders. Thus, the apparently positive effect of aging would be mitigated.

- Inheritance and aging: Until recently, inheritance seems to have played a minor role (Kessler, Masson, Pestieau (1991)). ${ }^{12}$ The personal assets of older people had not yet been massively revalued, while retirement pensions, although on the rise for the new cohorts of retirees, remained modest for those who had left the employment market fifteen years earlier in the sixties. This situation would change radically. There would be a strong increase in descending intergenerational flows of wealth. In other words, there would be an unprecedented - at least in modern history - boom in inheritances, inter vivos bequests, and assistance of all sorts. The laws of life being what they are, generations are destined to follow each other. The generations which are going to disappear will bequeath upon death, or transmit during their lifetimes, to the coming maturing generations the wealth which they succeeded in accumulating under good conditions in the sixties and seventies, which prospered exceptionally well in the eighties and which they will not need in the nineties due to the socialization of the financing of their retirement income. As for the beneficiary generations, their personal asset track record will be, shall we say, less brilliant - because of the cost of personal assets and the effort which must now be made to acquire them.

More substantial asset transfers will be made to less wealthy generations. Slowly but surely, there will be a move from wealth acquired through savings to wealth acquired through inheritance. ${ }^{13}$

This expanding trend in inheritances, which had been somewhat deferred due to the steady rise in life expectancy, will continue to accelerate. Today's rentiers will create tomorrow's heirs. These «new heirs» will be relatively old due to the rising life expectancy of their relatives. In France, the recent measure favouring inter vivos bequests, which may

12 We will not review here the extensive literature since A. Atkinson's seminal paper on the importance of inheritance. The debate on the importance of inherited wealth in existing wealth has been very animated (Modigliani (1988), Kotlikoff and Summers (1988)) and does not yet seem closed (Kessler and Masson (1989)).

${ }^{13}$ This trend has already begun. The proof of this is that the annual volume of inheritance and inter vivos bequests is estimated at almost 180 billion French francs, whereas the annual financial savings of all the French households does not exceed 300 billion French francs. This volume of asset transfers between generations represents about $1 \%$ of the total wealth of households and $3 \%$ of GDP. 
have surprised some, can therefore be easily explained: it is not desirable that households should systematically have to wait until their fifties and more, indeed their sixties, to be able to benefit from the transmission of funds.

This boom in inheritance and inter vivos bequests has also been noted across the Atlantic. As shown in Table 4, the volume of inheritances is apparently increasing rapidly in the United States.

Table 4: Trend in inheritance in the United States

\begin{tabular}{|c|c|c|c|}
\hline Year & $\begin{array}{c}\text { Total } \\
\text { billions USD }\end{array}$ & $\begin{array}{c}\text { Nber of heirs } \\
\text { (thousands) }\end{array}$ & $\begin{array}{c}\text { Average * } \\
\text { (USD) }\end{array}$ \\
\cline { 2 - 4 } 1990 & 39,4 & 900 & 43814 \\
1995 & $\mathbf{8 4 , 3}$ & 1506 & $\mathbf{5 5 9 5 1}$ \\
2000 & 143,8 & 2202 & 65289 \\
2005 & 216,9 & 2846 & 76194 \\
2010 & 286,2 & 3255 & $\mathbf{8 7 9 1 8}$ \\
2015 & 335,9 & 3389 & 99130 \\
2020 & 334,5 & 3135 & $\mathbf{1 0 6 7 1 7}$ \\
2025 & 288,5 & 2650 & 108870 \\
2030 & 201,6 & 1881 & 107180 \\
2035 & 106,8 & 1090 & 97997 \\
2040 & 40,7 & 417 & 97636 \\
\hline Total & 10365,0 & 114953 & 90167 \\
\hline
\end{tabular}

*1989 USD

Source: Avery et Rendall

However, the «comeback» of inheritances and inter vivos bequests will depend on the evolution of our pension system. Its magnitude will depend on the means of adjustment ultimately chosen to balance the pay-as-you-go pension schemes. Depending on whether the adjustment is brought to bear upon the contributions of the active population or upon the pensions of retirees, inheritance will or will not play a crucial role for future generations.

Public pension flows affect the private flows of inheritance and bequests, in the same way that social intermediation (through public transfer mechanisms) affects financial intermediation (through savings flows).

\subsubsection{Retirement and aging}

Pay-as-you-go pension schemes, whose very purpose is to transfer resources to that part of the population which is over a certain age, will inevitably be the first to be affected by the aging of the population.

Naturally, the pay-as-you-go schemes will be most directly and strongly affected. An O.E.C.D. study, which is based, however, on rather conservative assumptions (Table 5), has shown that public expenditures for retirement will increase from now to 2030 by more 
than $40 \%$ in Germany and Italy, by more than $30 \%$ in Belgium and the United Kingdom, by more than $60 \%$ in the Netherlands and, especially, by more than $75 \%$ in France! 14

Table 5: Forecast of trends in public expenditures and retirement

\begin{tabular}{|l|c|c|c|c|c|c|c|}
\hline & 1980 & 1990 & 2000 & 2010 & 2020 & 2030 & 2040 \\
\cline { 2 - 8 } Germany & 100 & 107 & 122 & 126 & 131 & 141 & 126 \\
Belgium & 100 & 103 & 104 & 112 & 124 & 135 & 136 \\
Denmark & 100 & 102 & 99 & 114 & 120 & 128 & 124 \\
France & 100 & 115 & 122 & 140 & 161 & 175 & 172 \\
United Kingdom & 100 & 102 & 98 & 107 & 116 & 136 & 130 \\
Italy & 100 & 109 & 114 & 126 & 136 & 143 & 134 \\
Japan & 100 & 138 & 180 & 219 & 220 & 216 & 229 \\
\hline
\end{tabular}

Source: O.E.C.D.

The deterioration of the "performance» of the public pension schemes which will result will be considerable. Why is this so? Quite simply because these systems function on a pay-as-you-go basis, i.e. they will finance the pensions paid to tomorrow's retirees by withholdings on tomorrow's active population, which will be proportionally less numerous than today. This is the direct application of the basic equation of the pay-as-you-go system:

\section{Contribution Rate $\mathrm{x}$ Average Income $\mathrm{x}$ Number of Working People $=$ Average Pensions x Number of Retirees.}

These developments would not be fundamentally jeopardized by phenomena such as an upturn in the fertility rate, continued immigration flows, a sharp increase in productivity or even a return to full employment.

In effect, even if fertility rates were to increase over the years to come, this would not modify the effects of the low fertility rates observed since 1965 . We have already said this, but it bears repeating: children not born in the past will never be born. An upturn in fertility rates would have an effect only towards the end of the projected period, i.e. around 2025-2040. Moreover, it would require an exceptional upturn in fertility rates to compensate for the aging of the population. The average number of children per woman would have to exceed three simply to maintain the retirees/working population ratio! This would entail an exceptional growth in population which would have to continue indefinitely, in order to avoid having to face even worse retirement problems. The French population, with this fertility rate, would reach 200 million in the year 2100,1 billion in 2200 and so on!

14 This is notably due to the fact that all the pension schemes in France operate according to the pay-as-you-go principle, both the first public pillar as well as the second professional pillar. 
With respect to immigration, the arguments look simple on paper. It would be sufficient to «fill up» the hollow parts of the age pyramid through recourse to foreign labour. However, the migratory flows would have to be massive. In the case of France, in order to maintain the dependency ratio, ceteris paribus, from 2005, it would take about 900,000 working immigrants per year to compensate for the arrival of 300,000 persons each year at retirement age from 2005 to 2020 .

An increase in productivity is also often mentioned as a way of offsetting the effects of aging on pay-as-you-go schemes. Here again, the arguments are straightforward: assuming that our children will be rich tomorrow - on account of a big increase in income from work due to significant gains in productivity - they will have no trouble allocating the extra income generated each year to contributions and taxes for retirees; and this increased burden will not reduce their net income. Two questions arise: (i) Where would these productivity gains come from? For economists, they would stem mainly from investment in human capital, in education and training. It has to be said that efforts in this area have been insufficient during the past years in most of the developed countries. (ii) Even if our children are wealthier than we are, will they accept, for all that, to have their productivity gains confiscated? This is an open question.

The prospects for our public pension schemes are worrying. Charts 13 and 14 show this clearly. In the French case, demographic prospects are such that, in the end, we will have to choose between a very high increase in contributions or a very great drop in the pension/salary replacement ratio (with an unchanged retirement age). Chart 13 shows that the contribution rate, expressed as a percentage of the average income of the working population, would rise from $20 \%$ in 1990 to almost $40 \%$ in 2035 . Chart 14 shows that maintaining the contribution rate at its 1990 level would cause the replacement rate to fall (average pension/salary) from 70 to $35 \%$.

Chart 13: Average of old age pension contributions as \% of gross salary of middle management employees to maintain statutory benefits at 1991 levels

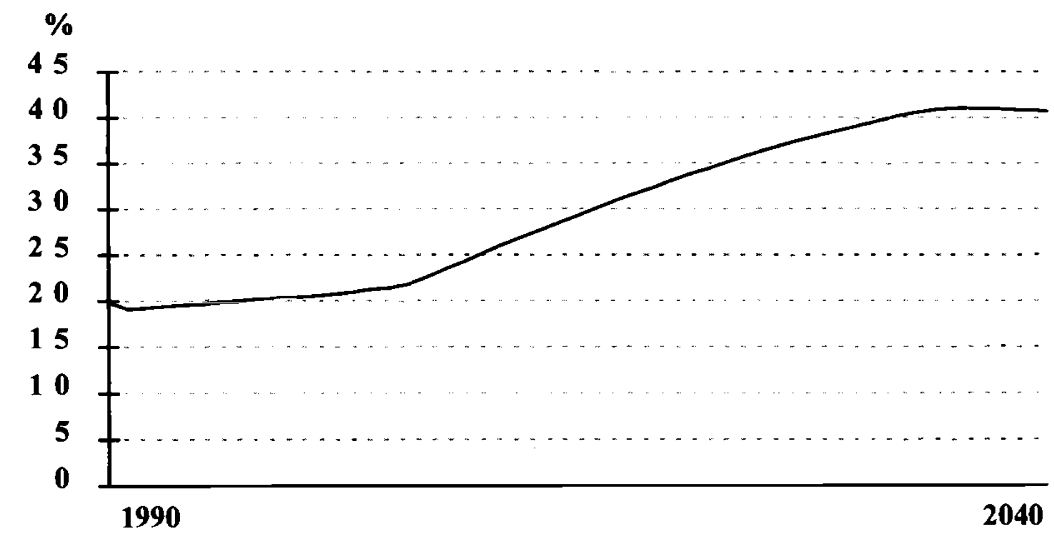

Source: QUANTIX 
Chart I4: Evolution of pensions of private sector employees at I99I levels: example of a middle management employee

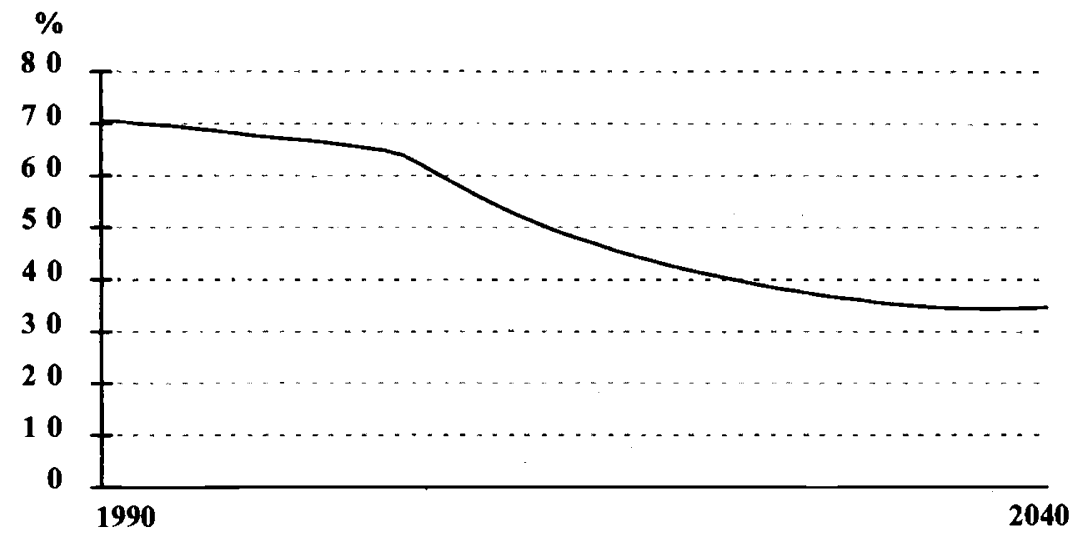

Source: QUANTIX

Will the pay-as-you-go schemes be able to adapt? The solutions are well known. They consist of: (i) increasing contributions and/or budgetary financing; (ii) pushing back the average retirement age; and (iii) lowering the relative value of pensions paid. They are, and will be, hard to implement, for economic, social and political reasons.

Some consider, wrongly, that increasing contributions or taxes is benign neglect. One should not forget the adverse economic effects of an increase in compulsory contributions. An increase in the rate of contributions causes a lowering of real income and/or profits, decreases competitiveness and brings about a substitution of capital for labour, thus favouring unemployment, fuelling inflation, and evicting savings. As for greater use of budgetary financing, this leads to a deepening of the public deficit or an increase in taxation, i.e. two «solutions» which have multiple, adverse effects, among which are the eviction of savings and inflationist tendencies. It also prevents the State from properly carrying out its other tasks, in particular its other social policies (family, urban, health...), the development of infrastructures, training and education, security, etc.

As regards pushing back the average retirement age, this runs up against strong political, social and also economic resistance. Prolonging the period of activity would require a change of mentality of both employers and employees. In order to strengthen this «fourth pillar» of the retirement system, ${ }^{15}$ a labour market for persons over age 60 would have to be set up. Experiments have been made to facilitate the economic and social insertion of older people, although they remain limited. There would have to be a real political will in the future to make it possible to durably increase activity rates at advanced ages.

Of course, there still remains the possibility of resorting to a lowering of the relative value of pensions paid (whether by modifying the calculation of pension rights or by

15 To use the expression proposed by the Geneva Association (Kessler (1988)). 
underindexing pensions paid). This would result in a deterioration of the relative situation of retirees as compared to working persons. No doubt that such an evolution seems necessary. Current beneficiaries as well as future beneficiaries will be affected by the inevitable drop in return of the pay-as-you-go pension schemes. Future beneficiaries have to be encouraged to set up additional individual and group arrangements to their pension plans, under proper prudential, social and fiscal conditions, to supplement the pension they will receive from the compulsory programs.

It is futile to ignore the facts. The aging of populations in all the industrialized countries will have a direct effect on all existing pay-as-you-go schemes. This obvious fact, which has been denied for too long, is now perceived by the public, which is beginning to have doubts about the solvency of these schemes. Thus, doubt has taken root and there is no reason why it should be removed (Lindbeck (1994), Kessler (1994)). The effort to accumulate assets for retirement will have to increase. It will have to be greater in countries which have been slow to react, such as France. ${ }^{16}$ Individuals, in response to these incentives, will have to continue and increase their efforts to save. It should be noted that, in numerous countries, the drop in the savings rates appears to be over. Moreover, investment in life insurance is developing in countries where pay-as-you-go schemes were the most generous (France, Italy, Spain). It is a sign that Europeans, worried about their future, have understood just what efforts are required. Jean-Baptiste Say used to say: «Have children or save!». Europeans have had few children over the past thirty years, so they will have to save more.

Whether we like it or not, aging will affect all social and public schemes operating transfers between age groups and, all the more, between successive generations. We can either let these transfers go down the drain, which will create rapidly uncontrollable tensions, or we can manage them, which will enable us to renew the fundamental social contract.

\section{Active management of the allocation of resources between generations is essential.}

In view of the prospects for the aging process of the European populations, all of the mechanisms for the transfer of resources between age groups will be given a rough ride. There are competing demands for a share of national income. As the income of the active population is not necessarily going to expand significantly - mainly because of the stagnation, indeed the decrease, in the number of active people, which will take place from the beginning of the next century - its allocation among the coexisting age groups will most likely be a source of increasing tension.

\subsection{A better understanding of the concept of justice between generations}

Whether public or private, income and wealth transfers modify the intergenerational distribution of well-being. What are the criteria to assess the resulting well-being distribution between successive generations? How can one say that a given intergenerational transfer is redistributive or anti-redistributive? How can one state that a given distribution

16 In any case, it will be necessary to ensure equality of competition between all of the players taking part in the development of individual and group funding arrangements, in particular insurers and pension funds. 
of well-being between successive generations is preferable to another distribution? What are the guidelines that a government can follow in order to maintain justice between coexisting and succcessive generations?

To answer these basic questions is not an easy task.

First, we all know how difficult it is to compare the well-being of different generations (Kessler and Masson (1995)). Since all their characteristics vary over time, the simplifying assumption of stationary states appears irrelevant. To stress only one example: how does one take into account the increase of life expectancy from one generation to the next?

Second, the concept of equality between successive generations is, of course, not relevant. The comparison between the intergenerational and the intragenerational distributions of income is indeed meaningless. Why should the average well-being of each successive generation be equal? Since we can assume a positive growth rate for the economy as a whole, in order to reach strict equality between successive generations there should be a huge stream of resources coming from the not-yet-born generations in favour of existing generations. This is, of course, very unrealistic.

Third, the comparison à la Kotlikoff of the trade-off between what a generation has received from other generations and what it has given is also subject to criticism. Even by including all possible transfers - from exhaustible resources to inheritances - the sum total may not lead to a definite conclusion that a given generation is a winner or a loser. An accounting framework is not sufficient to assess the relative well-being of generations.

Fourth, the use of an intergenerational collective utility function is certainly appealing, but its specification raises numerous theoretical questions. The maximization of such a collective utility function would determine the optimal level of consumption of each successive generation. The transfers would be made in such a way as to reach the optimal path of intergenerational consumption. There are, however, a certain number of problems to be solved. (i) How do we weight the utility of each generation according to its size? (ii) How do we choose the discount rate? There are, of course, other questions to be solved, but this approach is of little empirical relevance.

Fifth, the question of equity - and hence of justice - is even more perverse. Many transfers such as inheritance or income transfers through pay-as-you-go schemes appear somehow reciprocal. «I have inherited some wealth from my parents, and therefore I will transfer some wealth to my children»; «I have financed the retirement period of my parents and therefore I expect my children to finance my own retirement period». We face here the problem of intergenerational commitments. We see that if one generation changes the rules of the game - refuses to pay its contributions to the pay-as-you-go schemes, or consumes all inherited wealth without leaving, in turn, a bequest - the chainletter mechanism comes to an end, all previous (or later) transfers introducing a bias in the distribution of well-being between successive generations. Who can argue that there will never be a generation that will end the chain-letter mechanism of pay-as-you-go schemes? Who can argue that there will never be a government that will change the taxation of inheritance? Most of the transfers between generations will always be made in a context of uncertainty about the behaviour of yet unborn generations. 
The concept of justice between generations needs further analysis. ${ }^{17}$ Even if one cannot define with precision the concept of equality or equity between generations, it seems that if one generation (the winner) appears to benefit too much from intergenerational transfers - at the expense of previous or future generations (the losers) - there may be tensions and conflicts. We assume here that the situation described is a sharp deviation from the historical trend of intergenerational transfers.

\subsection{Two very contrasting scenarios can be outlined.}

According to the first scenario, these tensions will worsen and might even degenerate. If nothing is done, it is certain that there will be generations that will «benefit» from the aging process and others that will suffer from it. There will be «winners» and «losers», as David Thomson (1989) argued. Certain generations, i.e. today's young active population and the generations that will reach the age of activity in the decades to come, may be required to shoulder a very large part of the cost associated with aging. In particular, they will have to suffer increasing withholdings from their employment income in order to ensure the public retirement and health insurance transfers to their elders.

We may experience what is called in the literature, to use Margaret Mead's expression, a generation conflict. Certain generations - in this case, the emerging generations might consider that the burden placed on their shoulders is too heavy. Seeing their income drastically reduced by increased public and social withholdings, constantly doubting that there will be any subsequent returns from these withholdings, the emerging generations might question the choices made by the State. In order to protect their standard of living, they might express their refusal, by political and, if necessary, by non-political means, to be made to contribute beyond what they see as fair. The feeling of inequity or injustice is a powerful one and it has been at the root of many social conflicts throughout the world.

The problem would be worsened by the consequences of the aging of the electoral body. The electorate will get older, since the average age of the elector will certainly increase in the decades to come. Politico-economic models are already attempting to work out analytically the consequences of the aging of the electoral body. If one assumes that each generation tries, above all, to maximize its own interests when voting, the increasing weight of the older generations would result in a sharing out of available national resources in their favour. Politicians would be unable to escape this pressure and would be inclined to favour the elderly electorate. Thus, «generation conflicts» would succeed the so-called «class» conflicts. Of course, it is possible to criticize the somewhat mechanical aspect of these models and the theory of generational selfishness on which they are based, but it remains nevertheless true that they express a possible evolution which must not be casually brushed aside.

According to the second scenario, our societies would take the necessary steps although these may sometimes be painful - in time to avoid this conflict. Rather than passively allowing transfers between generations to evolve in favour of some and to the detriment of others, the State, which is responsible for implementing the majority of ascending

${ }^{17}$ See Daniels (1989). For a very stimulating discussion on the concept of intergenerational justice in the case of pension schemes, see Fleuarbey and Michel (1992). 
transfers, would take the necessary steps to avoid any distortion in the allocation of resources among the age groups. The State would exercise its role of umpire or arbitor between generations by establishing rules for an equitable sharing out of resources and ensuring that they are respected. The government would thus be an umpire rather than a player. According to this second scenario, the State would not be a prisoner of narrowminded electioneering, while each generation, upon voting, would seek the common interest rather than its own.

In any case, in view of the importance of private and public intergenerational transfers, it is necessary to better identify and measure them, to better evaluate their effects and master them, in a word, to manage them better.

\subsection{Better measurement of intergenerational transfers}

An «observatory» would be put in charge of keeping a sort of intergenerational accounting system which would be just as useful as the creation of the national accounting system was in its day. The lack of knowledge concerning transfers on the part of the authorities in particular and of the public in general is significant. Everyone seems to be entitled to claim a share of national resources for himself while neglecting the source of these transfers and ignoring the implicit or explicit arbitrage to which they lead.

Attempts at setting up this system of intergenerational accounting have already been made in the United States (Kotlikoff (1992), Auerbach, Gokhale and Kotlikoff (1994)). It is obvious that this accounting poses difficult problems of methodology (Buiter (1995)). First, one should of course be cautious when concluding on the effects of government intervention on intergenerational equilibria: the transfers themselves affect most economic variables. Second, generational accounts should be extended to include private income and wealth transfers. Third, the concept of an intergenerational accounting system is based on a rather static approach. It is a promising option, however.

Beyond mere measuring, no matter how useful, research must also be carried out on the underlying motives and effects of intergenerational transfers, be they public or private.

\subsection{Better management of intergenerational transfers}

We do not have enough points of reference which would allow us to set the basis for a real policy of resource allocation between generations. Most of the points of reference concerning the distribution of income in a given society do not deal with the problem of the sharing out of resources between generations.

It is remarkable how constantly the expression «solidarity» is used when speaking of transfers between generations. This notion, which is very important, is unfortunately of little operational use. How far should solidarity go? Just how much or how little solidarity is involved in deciding to tap the income of the working population to give to the older generations rather than the younger ones, or vice versa?

Given the responsibility of government in the field of transfers between generations, there will have to be a real political debate to determine the rules for collective action. In view of the prospects for a very sharp rise in transfers, limits will have to be traced in order 
to encompass the transfers of resources between generations, for two reasons: first, so that they do not have adverse economic and social consequences (on the labour market, on savings, on international competitiveness, etc.) and second, so that they do not have antiredistributive consequences. Naturally these norms would be spread over time. Budgets would have to be defined over several decades in order to fight against public «short-termism», 18

That said, the transition will not be easy. Whereas the dominant notion remains that of an equitable allocation of resources within the population in general, the concept of allocation between generations will have to be outlined. Contradictions may arise as soon as the following simple question is asked: how can we handle intragenerational solidarity and intergenerational solidarity at the same time?

\subsection{A few possible rules for guiding collective action}

We shall, perhaps somewhat daringly, outline a few rules which would respect both the principles of intergenerational equity and of justice between coexisting and successive generations, as well as the principles of intergenerational efficiency and of the pursuit of the accumulation of wealth over time.

- Massive investment in initial training, and reform of the education system so that it better contributes to the professional integration of the young generations. We are entering an era where the supply of the active population will slow down as a result of the drop in fertility rates. Consequently, it will be necessary to ensure that the generations which are numerically smaller are qualitatively better trained. Investment in training is a priority because the quality of human capital remains one of the essential sources of productivity gains, and therefore of growth. Moreover, in a free-market world, only high labour productivity will make it possible to resist ever fiercer competition, coming notably from low-wage countries.

- An extension of active life. This requires, in particular, pushing back the age limits for cessation of activity and also making profound changes in the ways in which this is done. Such an extension of active life could coincide with the development of concepts such as part-time work, flextime work, sabbatical leaves, etc. Obviously, such an extension of active life is justified by the extension of life itself. It should make it possible to avoid having an excessive concentration of producer generations as opposed to consumer generations.

- Base social contributions on total income. In a number of countries, the current methods of financing social transfers through payroll taxes lead to too great a generational concentration of resources. Thus, a movement towards a broad-based contribution system ${ }^{19}$ appears preferable in a period of population aging in order to avoid a minority of the population having to bear the burden of these compulsory contributions tomorrow.

\footnotetext{
${ }^{18}$ In this regard, the annual budget rule is very harmful for the long-term management of intergenerational transfers.

${ }^{19}$ Such as the «CSG» (Generalized Social Security Contribution) in France. It is a flat rate tax levied on all income.
} 
- Encourage the young to vote. Data available on enrollment on voting lists and on actual voting show that the younger generations use their voting rights less than their elders. Given the fact that the aging process increases the average age of voters and the importance of the role of the authorities in allocating resources among the generations, young people must be strongly encouraged to take part in democratic life by voting. One may wonder whether the introduction of compulsory voting - in force in some EU countries - would not be a means among others to avoid a certain bias in the expression of the general will.

- A modification of the age-income relationship. A review of the provisions linking salary and age which still exist in a large number of sectors and businesses should help to improve relations between generations. Salary differences between age groups, which are in no way justified by productivity differences, may mean that the young generations have to bear increasing costs during a period of aging of the active population. Paradoxically, the older generations also bear a part of this cost, insofar as employers have a tendency to get rid of elderly, costly manpower. Thus, to favour the employment of young people and to make it possible to keep elderly persons in their activity (by pushing back the age limit for ceasing one's activities), it appears necessary to innovate and to find new ways of remunerating work over the life course.

- Re-think the policy on health. It is striking that, generation after generation, a steadily increasing portion of health care expenditures, which is mainly paid for by the active population, is allocated to the older generations. The distribution of health care expenditures according to age is partly the reflection of choice of policy on health care. Thus, a strict control of health insurance spending helps to slow down increasing intergenerational transfers which cut back the net income of the active population. Moreover, the development of prevention would rebalance age-related health expenditures.

- Control public deficits. The public debt is a burden placed upon future generations, especially when public spending corresponds to transfer payments, repayment of which will drastically reduce their disposable income. In this regard, control of deficits and a policy of gradually absorbing the accumulated public debt (showing a positive primary budget balance) will help, in the future, to slacken the noose of compulsory contributions. Such a policy of budgetary rigour is all the more necessary since the State is investing less than in the past, that is, since the accumulation of public assets is growing less quickly than its liabilities.

- Refrain from creating social deficits. Although it is possible to envisage a deficit in public finances, once the government goes ahead with investments, there is no excuse for social financing deficits. The financing of transfer expenditures through borrowing seems wholly unjustified. In reality, social schemes should generate surpluses in order to cover a part of future expenses. Consequently, the rule should be positive balances, in order to accumulate reserves, and not merely break even.

- Encourage a huge effort in long-term savings for retirement. Governments should increasingly encourage people to finance their retirement by saving in order to avoid placing the financial burden of population aging on future generations. In time, this extra accumulation of resources will increase the level of national income, thus facili- 
tating the continuation of immediate transfer mechanisms between generations. Indeed, fresh savings make it possible to finance the investment required for a return to growth. Some of the beneficial effects of this accumulation of long-term savings created by the mechanisms of individual and group funding arrangements would be to strengthen financial markets and favour the optimal allocation of capital, to ensure a non-inflationist financing of the economy, to help bring down real interest rates, to encourage investment, competitiveness and employment. These beneficial effects would make possible an effective transfer of resources in time. Following the same line of reasoning, encouraging people to insure themselves while they are active against the risk of being dependent when they are not, would also make it possible to avoid placing a burden - an extra financial charge - on the generations of tomorrow and beyond.

- Encourage the transmission of wealth. Since the transmission of wealth (i.e. inter vivos bequests, assistance, inheritances) is a phenomenon of the reduction of inequality between generations, encouraging bequests and assistance and refraining from increasing inheritance tax should help to avoid an increase in the wealth/assets gap between generations. Taking into account the fact that four generations now coexist, specific measures should be envisaged to encourage the transfer of wealth from grandparents to grandchildren, or indeed to great-grandchildren.

The greatness of a nation lies in its ability to ask itself, at the right time, the key questions which govern its future. The present system of private and public intergenerational transfers cannot last in the long run. The continuation of this system is impossible in view of the aging of the population. Therefore, it will have to be modified in order to keep predictable tensions from degenerating into real conflicts. The sooner, the better. 


\section{REFERENCES}

ARROW, Kenneth J., (1963), «Uncertainty and the Welfare Economics of Medical Care», American Economic Review, 53:5, 941-973.

AUERBACH, Alan J., JAGADEESH, Gokhale and KOTLIKOFF, Laurence J. (1994), «Generational Accounting: A Meaningful Way to Evaluate Fiscal Policy», Journal of Economic Perspectives, Vol. 8, No. 1, Winter, 73-94.

BIRNBACHER, Dieter, (1994), La responsabilité envers les générations futures, PUF.

BLANCHET, Didier et KESSLER, Denis, (1990), «Prévoir les effets économiques du vieillissement», Economie et Statistiques, No. 233, juin, 9-17.

BLANCHET, Didier et KESSLER, Denis, (1991), «L'allongement de l'espérance de vie et l'avenir des retraites», in L'avenir de l'espérance de vie, INED, Congrès et Colloques, No. 12, 65-78.

BOURGUIGNON, François et KESSLER, Denis, (1994), «Assurance sociale», Risques, No. 17, 19-23.

BUITER, Willem H., (1995), «Generational Accounts, Aggregate Saving and Intergenerational Distribution», NBER Working Paper, No. 5087, April.

CREMER, Helmut, KESSLER Denis and PESTIEAU Pierre, (1992), «Intergenerational Transfers Within the Family», European Economic Review, No. 36, 1-16.

DANIELS, Norman, (1989), «Justice and Transfers between Generations», in Johnson, Paul, Conrad Christoph and Thomson David, Eds., (1989), Workers versus Pensioners, Intergenerational Justice in an Ageing World, Center for Economic Policy Research, Manchester University Press, 57-79.

FLEUARBEY, Marc et MICHEL, Philippe (1992), «Quelle justice pour les retraites?», Revue d'économie financière, No. 23, 47-64.

GOLLIER, Christian et KESSLER, Denis, (1994), «Limites de l'assurabilité», Risques, No. 17, 89-92.

KESSLER, Denis, (1988), «The Four Pillars of Retirement», The Geneva Papers on Risk and Insurance, Vol. 13, No. 49, 342-349.

KESSLER, Denis, (1989), «But Why Is There Social Security?», in Johnson, Paul, Conrad Christoph and Thomson David, Eds., (1989), Workers versus Pensioners, Intergenerational Justice in an Ageing World, Center for Economic Policy Research, Manchester University Press, 80-90.

KESSLER, Denis, (1990), «L'arbitre des générations», Le Débat, No. 60, mai-août, 271-277.

KESSLER, Denis, (1990), «On the Economics of Intergenerational Transfers», Journal of Population Economics, June.

KESSLER, Denis, (1992), «Fortune acquise, fortune transmise», Option Finance, avril.

KESSLER, Denis, (1992), Comments on «Uncertainty under the Welfare State» by Assar Lindbeck, The Geneva Papers, Vol. 73, 394-396.

KESSLER, Denis and MASSON, André, (1989), «Bequests and Wealth Accumulation: Are There Some Pieces of the Puzzle Missing?», Journal of Economic Perspectives.

KESSLER, Denis et MASSON, André, (1995), «Redistribution et politique sociale: la double dimension de l'âge et de la génération», in Les Retraites - Génèse, acteurs, enjeux, livre collectif à la mémoire d'Edgard Andréani (sous la direction de Bernard Cochemé et Florence Legros), Ed. Armand Colin, 229-260.

KESSLER, Denis, MASSON, André et PESTIEAU, Pierre, (1991), «Trois vues sur l'héritage, la famille, la propriété, l'Etat», Economie et Prévision, No. 100-101, 1-29. 
KESSLER, Denis and PESTIEAU, Pierre, (1991), «The Taxation of Wealth in the EEC: Facts and Trends», Canadian Public Policy, Vol. XVII, No. 3, 309-321.

KOTLIKOFF, Laurence J. and SUMMERS, Lawrence H., (1988), «The Contribution of Intergenerational Transfers to Total Wealth: A Reply», in Kessler, Denis and Masson, André, Eds., Modelling the Accumulation and Distribution of Wealth, Oxford University Press, 53-68.

KOTLIKOFF, Laurence, (1992), Generational Accounting, Free Press, New York.

LAZEAR, Edward P., (1979), «Why Is There Mandatory Retirement?», Journal of Political Economy, 87.

LINDBECK, Assar, (1994), «Uncertainty Under the Welfare State», The Geneva Papers, No. 73, 394396.

MASSON, André, (1994), «L'héritage au sein des transferts entre générations», Théorie constat, perspectives, Mimeo.

MODIGLIANI, Franco, (1988), «The Contribution of Intergenerational Transfers to Total Wealth: Conceptual Issues and Empirical Findings», in Kessler, Denis and Masson André, Eds., Modelling the Accumulation and Distribution of Wealth, Oxford University Press, 21-52.

SHAPIRO, Harvey, (1994), «The Coming Inheritance Bonanza», Institutional Investor, June, 143-148.

THOMSON, David, (1989), «The Welfare State and Generation Conflict: Winners and Losers», in Johnson, Paul, Conrad Christoph and Thomson David, Eds., (1989), Workers versus Pensioners, Intergenerational Justice in an Ageing World, Center for Economic Policy Research, Manchester University Press, 33-56.

VALLIN, Jacques, (1991), Risques, «Evolution de la mortalité: hypothèses pour les années futures», No. 5, 15-36.

ZIMMERMANN, Klaus F., (1995), "Tackling the European Migration Problem», Journal of Economic Perspectives, Vol. 9, No. 2, Spring, 45-62. 